\title{
Pharmacological activities of Ballota acetabulosa (L.) Benth:A mini review
}

\begin{abstract}
The Ballota L. genera belonging to the Lamiaceae family found mainly in the Mediterranean area, Middle East, and North Africa. From the ancient times this genus has been largely explored for their biological properties. Phytochemical investigations of Ballota species have revealed that diterpenoids are the main constituents of the genera. A large number of flavonoids and other metabolites were also identified. This mini review covers the traditional and pharmacological properties of Ballota acetabulosa (L.) Benth species.
\end{abstract}

Volume 8 Issue 3 - 2020

\author{
Sanjay Kumar,' Reshma Kumari² \\ 'Department of Botany, Govt. P.G. College, India \\ ${ }^{2}$ Department of Botany and Microbiology, Gurukula Kangri \\ Vishwavidhyalaya, India
}

\author{
Correspondence: Reshma Kumari, Department of Botany \\ and Microbiology, Gurukula Kangri Vishwavidhyalaya, \\ Haridwar-249404, India, Tel +918755388I32, \\ Email reshmagupta5@gmail.com \\ Received: May 15, 2020 | Published: June 22, 2020
}

\section{Introduction}

All over the world various plants have been used as medicine. More recently, plant extracts have been developed and proposed for various biological process. In developing countries herbal medicine has been improved as a substitute solution to health problems and costs of pharmaceutical products. The development of drug resistance pathogens against antibiotics has required a search for new antimicrobial substances from other sources, including plants. Plants contain a wide range of substances that are used to treat chronic as well as infectious diseases. ${ }^{1}$

The genus Ballota L. (Lamiaceae) consists of about 33 species growing mainly in the Mediterranean region. In Turkey, the genus Ballota is represented by 11 species, 6 subspecies, 10 of which are endemic. ${ }^{2}$ B. acetabulosa was first described by Carl von Linnaeus as Marrubium acetabulosum in $1753^{3}$ and later on taxonomically described in its current nomenclature by George Bentham in $1834 .{ }^{4}$ This species is used as a remedy for wounds and burns. Aerial plant part may serve as Natural food preservative. ${ }^{5}$

\section{Habitat and distribution}

Plant found in rocks and rough ground in dry hills, well-drained sand, chalk, loamy soil. ${ }^{6,7}$ It usually grows at an elevation up to 900 m. ${ }^{6,8}$ This plant is native to East Aegean Islands, Greece, Kriti, Turkey and Turkey-in-Europe. ${ }^{7}$

\section{Botanical description}

Shrubs up to $60 \mathrm{~m}$., stem erect up to $80 \mathrm{~cm}$ long, woolly haired, port dense, rounded compact. Leaves evergreen, thick, fluffy, drawing greyish to green on white, opposite, ovate serrated, wavy margin, aromatic, small whorls, 2-lipped flowered; petiole small, toothed and rounded, diameter up to $5 \mathrm{~cm}$. Flowers small hermaphrodite, grouped in small whorled ears and foliate; calyx green, elongate, $1.5 \mathrm{~cm}$ long, funnel shaped, widens with a diameter of $2 \mathrm{~cm}$ after flowering; corolla, purple and white, just above the calyx. Fruit small, trigons, pink mottled, scratched violet-purple. ${ }^{7,9,10}$

\section{Pharmacological activity}

Dugler and Dugler investigated the antimicrobial activities of methanolic leaf extracts of $B$. acetabulosa by disc diffusion and microdilution method against Enterococcus faecalis, Escherichia coli, Klebsiella pneumoniae, Pseudomonas aeruginosa, Proteus mirabilis and Candida albicans pathogens causing complicated urine tract infections. They observed strong antimicrobial activity against $E$. coli (ZOI-18.6 mm), with MIC (MBC) of 32(64) $\mathrm{mg} / \mathrm{mL} .{ }^{11}$ Dulger and Kilcik studied the antifungal activities of ethanol extracts prepared from the leaves, rootstock and the combined formulation of $B$. acetabulosa against medical yeast Candida species (C. albicans ATCC 10231, C. tropicalis ATCC 13803 and C. guilliermondii ATCC 6260) and Cryptococcus species (C. neoformans ATCC 90112 and C. laurentii ATCC 34142) by the visual broth macrodilution method. They observed a strong antifungal effect against Candida species compared to Cryptococcus species (MIC-3.12 to $25 \mathrm{mg} / \mathrm{mL}$ ). ${ }^{8}$

\section{Phytochemical contents}

The phytochemical research of $B$. acetabulosa led the isolation and identification of several groups of phytochemical constituents. We have briefly summarized various phytochemicals of $B$. acetabulosa in Table 1.

\section{Therapeutic properties}

Whole plant has anti-microbial, anti-diabetic, depressant, diuretic, stimulant, spasmolytic, sudorific and expectorant properties. ${ }^{10}$ Aerial part posses anti-inflammatory activity, anti-tussive activity, ${ }^{8,18}$ antioxidant activity ${ }^{19}$ and anti-microbial activity. $8,18,20$

\section{Medicinal uses}

B. acetabulosa is mainly used to treat cough and cold, ${ }^{8}$ gastrointestinal disorder, ${ }^{5}$ haemorrhoids, ${ }^{21}$ wounds and burns, ${ }^{8,22}$ nephrolithiasis, gout, diabetes, as well as depression, anxiety and hysteria. ${ }^{10}$ In homeopathy it is used in the form of anti-cough tincture, insomnia and nervous system disorders. ${ }^{10}$ 
Table I Different phytochemical contents of B. acetabulosa

\begin{tabular}{|c|c|}
\hline Phytochemicals & Name \\
\hline \multirow[t]{2}{*}{ Labdane diterpenes } & Ballonigrin, dehydrohispanolone (hispanone) ${ }^{11,12}$ \\
\hline & I8-hydroxyballonigrin ${ }^{13}$ \\
\hline \multirow[t]{4}{*}{ Flavones } & Apigenin ${ }^{14,15}$ \\
\hline & Ladanein $^{12}$ \\
\hline & Scutellarein 7,4'-dimethyl ether ${ }^{14,15}$ \\
\hline & Luteolin $^{16}$ \\
\hline \multirow[t]{3}{*}{ Flavone glycosides } & Apigenin-7-O- $\beta$-D-glucopyranoside ${ }^{17}$ \\
\hline & Acacetin-7-O- $\beta$-D-glucopyranoside ${ }^{14,15}$ \\
\hline & Chrysoeriol-7-O- $\beta$-D-glucopyranoside ${ }^{14,15}$ \\
\hline Flavonol glycosides & Rutin $^{16}$ \\
\hline Acyl flavonoid glycosides & $\begin{array}{l}\text { Apigenin-7-O- } \beta \text {-D-(4"-E-p-coumaroyl)glucopyranoside (echinaticin); chrysoeriol-7-O- } \beta-D-\left(3^{\prime \prime}-E-p-\right. \\
\text { coumaroyl)-glucopyranoside; chrysoeriol-7-O- } \beta-D-\left(3^{\prime \prime}-Z-p-c o u m a r o y l\right) g l u c o p y r a n o s i d e 5^{17}\end{array}$ \\
\hline \multirow[t]{2}{*}{ Flavanones, flavanone glycosides } & Naringenin ${ }^{16}$ \\
\hline & Naringin ${ }^{16}$ \\
\hline Carboxylic acids & Caffeic acid, chlorogenic acid, E-coumaric acid, gallic acid, rosmarinic acid ${ }^{16}$ \\
\hline Other metabolites & Oleuropein ${ }^{16}$ \\
\hline
\end{tabular}

\section{Conclusion}

In this mini review we have briefly summarized the traditional uses, ethnobotanical description, ethnopharmacological properties and phytochemical constituents that have been isolated from $B$. acetabulosa. This mini review highlights the significance of the ethnopharmacological properties of $B$. acetabulosa, and research on $B$. acetabulosa should be encouraged. Further research should be conducted to explore new potential therapeutic agents and their ethnopharmacological properties for the treatment of life-threatening diseases.

\section{Acknowledgments}

None.

\section{Conflicts of interest}

The authors declare that they have no conflict of interest.

\section{References}

1. Yilmaz BS. Antilisterial activity of Ballota species growing in Turkey Ankara Üniversitesi Eczacılık Fakültesi Dergisi. 2005;34(3):155-164.

2. Davis PH. Flora of Turkey and the East Aegean Islands. Edinburgh: Edinburgh University Press; 1982.

3. Von Linne C. Species plantarum; 1753.

4. Bentham G. Labiatarum Genera et Species; 1834.

5. Dulger B, Kilcik M. Antibacterial activity of Ballota acetabulosa against methicillin-resistant Stapylococcus aureus. Asian Journal of Chemistry. 2011b;23(1):416-418.

6. Polunin O, Huxley A. Flowers of the Mediterranean. Hogarth Press; 1987.

7. Ballota acetabulosa [Online]. The Royal Horticultural Society; 2020.
8. Dulger B, Kilcik M. Antifungal activity of Ballota acetabulosa against yeast Candida and Cryptococcus species. Asian Journal of Chemistry. 2011a;23(1):413-415.

9. Huxley A. The New RHS Dictionary of Gardening. MacMillan Press; 1992.

10. Konstant M, Marcelos MA, Andrikou-Kalesoglou E, e al; Medicinal Herbs of Epirus [Online]. Epirus: University of Ioannina; 2020.

11. Dulger B, Dulger G. Antimicrobial activity of the leaves of Ballota acetabulosa on microorganisms isolated from urinary tract infections. Turk J Pharm Sci. 2012;9(3):257-262.

12. Yilmaz BS, Çitoğlu GS. High performance liquid chromatographic analysis of some diterpenoids of the Ballota species. FABAD J Pharm Sci. 2003;28:13-17.

13. Citoglu G, Yilmaz B, Tarikahya B, e al. Chemotaxonomy of Ballota species. Chemistry of Natural Compounds. 2005;41:299-302.

14. Savona G, Piozzi F, Hanson JR., e al. 18-Hydroxyballonigrin, a new diterpenoid from Ballota acetobulosa. Journal of Chemical Society, Perkin Transactions 1. 1978;10:1271-1272.

15. Meriçli A, Meriçli F, Tuzlaci E. Flavonoids of Ballota acetabulosa. Acta Pharmaceutica Turcica. 1988;30:143-144.

16. Sever-Yilmaz B, Saltan-Citoglu G. Chemical constituents of Ballota L. species. Ankara Universitesi Eczacilik Fakultesi Dergisi. 2003;37:53-59.

17. Askun T, Tekwu EM, Satil F, e al. Preliminary antimycobacterial study on selected Turkish plants (Lamiaceae) against Mycobacterium tuberculosis and search for some phenolic constituents. BMC Complement Altern Med. 2013; $13: 365$.

18. Dulger B, Dulger G. Antimicrobial activity of the leaves of Ballota acetabulosa on microorganisms isolated from urinary tract infections. Turk J Pharm Sci. 2012;9(3):257-262.

19. Sahpaz S, Skaltsounis AL, Bailleul FJ. Polyphenols from Ballota acetabulosa. Biochemical Systematics and Ecology. 2002;30(6):601-604. 
20. Pullaiah T. Encyclopaedia of herbal antioxidants. New Delhi, India: Regency Publication; 2012.

21. Dulger B, Sener A. Evaluation of antimicrobial activity of Ballota acetabulosa. African Journal of Microbiology Research .2010;4(12):12351238.
22. Citoğlu GS, Coban T, Sever B, e al. Antioxidant properties of Ballota species growing in Turkey. J Ethnopharmacol. 2004;92(2-3):275-280.

23. Siciliano T, Bader A, Vassallo A, e al. Secondary metabolites from Ballota undulata (Lamiaceae). Biochemical Systematics and Ecology. 2005;33(4):341-351. 